REINFORCED CONCRETE DESIGN 
Other Macmillan titles of interest to civil engineers

Hulse/Mosley Reinforced Concrete Design by Computer

Bolton Guide to Soil Mechanics

Boxer Work Out Fluid Mechanics

Jackson/Dhir Civil Engineering Materials, 4th edition

John Work Out Engineering Materials

Newton Structural Design

Salter Highway Design and Construction, 2nd edition

Salter Highway Traffic Analysis and Design, 2nd edition

Seeley Civil Engineering Contract Administration and Control

Seeley Civil Engineering Quantities

Seeley Civil Engineering Specification

Spencer Fundamental Structural Analysis

Stone $\quad$ Management of Engineering Projects

Uren/Price Surveying for Engineers, 2nd edition

Wilson Engineering Hydrology, 4th edition 


\title{
REINFORCED CONCRETE DESIGN
}

\author{
W. H. Mosley \\ and \\ J. H. Bungey \\ Department of Civil Engineering \\ University of Liverpool
}

FOURTH EDITION

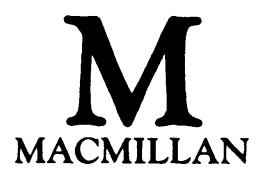


(C) W. H. Mosley and J. H. Bungey 1976, 1982, 1987, 1990

All rights reserved. No reproduction, copy or transmission of this publication may be made without written permission.

No paragraph of this publication may be reproduced, copied or transmitted save with written permission or in accordance with the provisions of the Copyright, Designs and Patents Act 1988, or under the terms of any licence permitting limited copying issued by the Copyright Licensing Agency, 33-4 Alfred Place, London WC1E 7DP.

Any person who does any unauthorised act in relation to this publication may be liable to criminal prosecution and civil claims for damages.

First published 1976

Reprinted 1977, 1978, 1980, 1981 (twice)

Second edition 1982

Reprinted 1983, 1984, 1985, 1986

Third edition 1987

Reprinted 1988, 1989

Fourth edition 1990

Reprinted 1991

Published by

MACMILLAN EDUCATION LTD

Houndmills, Basingstoke, Hampshire RG21 2XS

and London

Companies and representatives

throughout the world

British Library Cataloguing in Publication Data

Mosley, W. H. (William Henry)

Reinforced concrete design. - 4th ed.

1. Reinforced concrete structural components. Design

I. Title II. Bungey, J. H. (John Henry), 1944-

624.18341

ISBN 978-0-333-53718-3

ISBN 978-1-349-20929-3 (eBook)

DOI 10.1007/978-1-349-20929-3 


\section{Contents}

Preface to Fourth Edition viii

Notation ix

1 Properties of Reinforced Concrete 1

1.1 Composite Action 1

1.2 Stress-Strain Relations 2

$\begin{array}{lll}1.3 & \text { Shrinkage and Thermal Movement } & 7\end{array}$

1.4 Creep 11

$\begin{array}{ll}1.5 & \text { Durability } \\ 1.6 & 12\end{array}$

$\begin{array}{lll}1.6 & \text { Specification of Materials } & 12\end{array}$

2 Limit State Design $\quad 15$

$\begin{array}{lll}2.1 & \text { Limit States } & 16\end{array}$

2.2 Characteristic Material Strengths and Characteristic Loads 17

$\begin{array}{ll}2.3 \text { Partial Factors of Safety } & 18\end{array}$

$\begin{array}{ll}2.4 \text { Global Factor of Safety } & 19\end{array}$

3 Analysis of the Structure $\quad 24$

3.1 Loads 24

3.2 Load Combinations 26

3.3 Analysis of Beams and Frames 28

3.4 Redistribution of Moments 48

4 Analysis of the Section $\quad 53$

4.1 Stress-Strain Relations $\quad 53$

4.2 The Distribution of Strains and Stresses across a Section 55

4.3 Bending and the Equivalent Rectangular Stress Block 57

4.4 Singly Reinforced Rectangular Section in Bending 58

4.5 Rectangular Section with Compression Reinforcement at the
Ultimate Limit State

4.6 Flanged Section in Bending at the Ultimate Limit State 68

4.7 Moment Redistribution and the Design Equations 75 
4.8 Bending Plus Axial Load at the Ultimate Limit State 79

4.9 The Rectangular-Parabolic Stress Block 88

4.10 The Triangular Stress Block $\quad 91$

5 Shear, Bond and Torsion $\quad 98$

$\begin{array}{llr}5.1 & \text { Shear } & 98\end{array}$

$\begin{array}{lr}5.2 \text { Anchorage Bond } & 103\end{array}$

5.3 Laps in Reinforcement 106

5.4 Analysis of Section Subject to Torsional Moments 107

6 Serviceability, Durability and Stability Requirements 112

$\begin{array}{ll}\text { 6.1 Detailing Requirements } & 113\end{array}$

6.2 Span-Effective Depth Ratios $\quad 117$

$\begin{array}{ll}\text { 6.3 Calculation of Deflections } & 119\end{array}$

$\begin{array}{lll}6.4 & \text { Flexural Cracking } & 134\end{array}$

$\begin{array}{ll}\text { 6.5 Thermal and Shrinkage Cracking } & 141\end{array}$

6.6 Other Serviceability Requirements 144

$\begin{array}{lll}6.7 & \text { Stability } & 147\end{array}$

7 Design of Reinforced Concrete Beams 154

7.1 Preliminary Analysis and Member Sizing 156

$\begin{array}{ll}7.2 \text { Design for Bending } & 159\end{array}$

$\begin{array}{ll}7.3 \text { Design for Shear } & 174\end{array}$

$\begin{array}{ll}7.4 \text { Bar Spacing } & 180\end{array}$

$\begin{array}{ll}7.5 \text { Continuous Beams } & 180\end{array}$

$\begin{array}{ll}7.6 \text { Cantilever Beams } & 187\end{array}$

$\begin{array}{ll}7.7 & \text { Design for Torsion } \\ \end{array}$

8 Design of Reinforced Concrete Slabs $\quad 192$

$\begin{array}{ll}8.1 \text { Simplified Analysis } & 192\end{array}$

$\begin{array}{ll}\text { 8.2 Shear in Slabs } & 193\end{array}$

8.3 Span-Effective Depth Ratios $\quad 198$

8.4 Reinforcement Details 200

8.5 Solid Slabs Spanning in One Direction 201

8.6 Solid Slabs Spanning in Two Directions 209

8.7 Flat Slab Floors 214

8.8 Ribbed and Hollow Block Floors 222

$\begin{array}{lll}8.9 \text { Stair Slabs } & 226\end{array}$

8.10 Yield Line and Strip Methods 230

9 Column Design $\quad 239$

$\begin{array}{ll}9.1 \text { Loading and Moments } & 239\end{array}$

9.2 Short and Slender Columns 241

9.3 Reinforcement Details 244

9.4 Design of Short Columns 246

9.5 Non-rectangular Sections $\quad 261$

9.6 Design of Slender Columns 264 
10 Foundations $\quad 270$

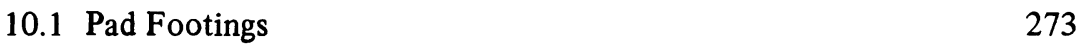

$\begin{array}{ll}10.2 \text { Combined Footings } & 280\end{array}$

$\begin{array}{ll}10.3 \text { Strap Footings } & 284\end{array}$

$\begin{array}{ll}10.4 \text { Strip Footings } & 286\end{array}$

$\begin{array}{ll}10.5 \text { Raft Foundations } & 289\end{array}$

10.6 Piled Foundations $\quad 291$

11 Water-retaining Structures and Retaining Walls 296

11.1 Water-retaining Structures 296

11.2 Joints in Water-retaining Structures 298

$\begin{array}{ll}11.3 \text { Reinforcement Details } & 302\end{array}$

$\begin{array}{ll}11.4 \text { Design Methods } & 304\end{array}$

$\begin{array}{ll}11.5 \text { Retaining Walls } & 318\end{array}$

12 Prestressed Concrete $\quad 329$

12.1 Principles of Prestressing 329

12.2 Methods of Prestressing $\quad 332$

12.3 Analysis of Concrete Section Under Working Loads 335

12.4 Design for the Serviceability Limit State 341

12.5 Analysis and Design at the Ultimate Limit State 367

$\begin{array}{ll}\text { Appendix } & 382\end{array}$

Further Reading $\quad 386$

$\begin{array}{ll}\text { Index } & 388\end{array}$ 


\section{Preface to Fourth Edition}

The purpose of this book is to provide a straightforward introduction to the principles and methods of design for concrete structures. It is directed primarily at students and young designers who require an understanding of the basic theory and a concise guide to design procedures. Although the detailed design methods are generally according to British Standards, much of the theory and practice is of a fundamental nature and should, therefore, be useful to engineers in other countries. Limit state concepts, as recently introduced in the new Codes of Practice, are used and the calculations are in SI units throughout.

The subject matter has been arranged so that chapters 1 to 5 deal mostly with theory and analysis while the subsequent chapters cover the design and detailing of various types of member and structure. In order to include topics that are usually in an undergraduate course, there is a chapter on earth-retaining and water-retaining structures, and also a final chapter on prestressed concrete.

Important equations that have been derived within the text are highlighted by an asterisk adjacent to the equation number.

In preparing the fourth edition of this book, the principal aim has been to incorporate new information relating to the design of water-retaining structures, as proposed by British Standard BS 8007. The remainder of the text, which relates to BS 8110 , remains essentially unchanged with only very minor amendments.

It should be mentioned that standard Codes of Practice such as BS 8110 are always liable to be revised, and readers should ensure that they are using the latest edition of any relevant standard.

Extracts from the British Standards are reproduced by permission of the British Standards Institution, 2 Park Street, London W1A 2BS, from whom complete copies can be obtained.

Finally, the authors wish to thank Mrs B. Cotgreave who prepared the diagrams and Mrs F. Zimmermann who typed most of the draft and final copies of the manuscript. 


\section{Notation}

Notation is generally in accordance with BS 8110 , and the principal symbols are listed below. Other symbols are defined in the text where necessary. The symbols $\epsilon$ for strain and $f$ for stress have been adopted throughout, with the general system of subscripts such that the first subscript refers to the material, $\mathrm{c}$ - concrete, $\mathrm{s}$ - steel, and the second subscript refers to the type of stress, $\mathrm{c}$ - compression, $\mathrm{t}-$ tension.

$\begin{array}{ll}A_{\mathrm{s}} & \text { Cross-sectional area of tension reinforcement } \\ A_{\mathrm{s}}^{\prime} & \text { Cross-sectional area of compression reinforcement } \\ A_{\mathrm{sb}} & \text { Cross-sectional area of shear reinforcement in the form of bent-up bars } \\ A_{\mathrm{sv}} & \text { Cross-sectional area of shear reinforcement in the form of links } \\ a & \text { Deflection } \\ a_{\mathrm{cr}} & \text { Distance from surface crack position to point of zero strain } \\ b & \text { Width of section } \\ b_{\mathrm{v}} & \text { Breadth of web or rib of a member } \\ b_{\mathrm{w}} & \text { Breadth of web or rib of a member } \\ d & \text { Effective depth of tension reinforcement } \\ d^{\prime} & \text { Depth to compression reinforcement } \\ E_{\mathrm{c}} & \text { Static secant modulus of elasticity of concrete } \\ E_{\mathrm{s}} & \text { Modulus of elasticity of steel } \\ e & \text { Eccentricity } \\ F & \text { Ultimate load } \\ f_{\mathrm{cu}} & \text { Characteristic concrete cube strength } \\ f_{\mathrm{pu}} & \text { Characteristic strength of prestressing tendons } \\ f_{\mathrm{s}} & \text { Service stress or steel stress } \\ f_{\mathrm{y}} & \text { Characteristic strength of reinforcement } \\ f_{\mathrm{yv}} & \text { Characteristic strength of link reinforcement } \\ G_{\mathrm{k}} & \text { Characteristic dead load } \\ g_{\mathrm{k}} & \text { Characteristic dead load per unit length or area } \\ h & \text { Overall depth of section in plane of bending } \\ h_{\mathrm{f}} & \text { Thickness of flange } \\ I & \text { Second moment of area } \\ k_{1} & \text { Average compressive stress in the concrete for a rectangular-parabolic } \\ & \text { stress block }\end{array}$


$k_{2} \quad$ A factor that relates the depth to the centroid of the rectangularparabolic stress block and the depth of the neutral axis

$l_{\mathrm{a}} \quad$ Lever-arm factor $=z / d$

$l_{\mathrm{e}} \quad$ Effective height of a column or wall

$M \quad$ Bending moment

$M_{\mathbf{u}} \quad$ Ultimate moment of resistance

$N \quad$ Axial load

$n \quad$ Ultimate load per unit area

$N_{\text {bal }} \quad$ Axial load on a column corresponding to the balanced condition

$P \quad$ Final prestress force (chapter 12)

$Q_{\mathrm{k}} \quad$ Characteristic imposed load

$q_{\mathrm{k}} \quad$ Characteristic live load per unit length or area

$1 / r_{x} \quad$ Curvature of a beam at point $x$

$r_{\text {crit }} \quad$ Critical steel ratio to control thermal cracks

$s \quad$ Depth of equivalent rectangular stress block

$s_{\max } \quad$ Maximum likely crack spacing

$s_{\mathbf{v}} \quad$ Spacing of links along the member

$T \quad$ Torsional moment

$u \quad$ Perimeter

$V \quad$ Shear force

$v \quad$ Shear stress

$v_{\mathrm{c}} \quad$ Ultimate shear stress in concrete

$W_{\mathrm{k}} \quad$ Characteristic wind load

$w_{\max } \quad$ Maximum likely surface crack width

$w_{\mathrm{u}} \quad$ Ultimate load per unit length

$x \quad$ Neutral axis depth

$z \quad$ Lever arm

$\alpha_{c} \quad$ Coefficient of thermal expansion of mature concrete

$\alpha_{\mathrm{e}} \quad$ Modular ratio

$\gamma_{f} \quad$ Partial safety factor for load

$\gamma_{m} \quad$ Partial safety factor for strength

$\epsilon_{\mathrm{sh}} \quad$ Shrinkage strain

$\mu \quad$ Coefficient of friction

$\Phi \quad$ Bar size

$\phi \quad$ Creep coefficient 